\title{
Promoting academic integrity through a stand-alone course in the learning management system
}

\author{
M. Sara Lowe ${ }^{1 *}$ (D), Gina Londino-Smolar ${ }^{2}$, Kenneth E. A. Wendeln ${ }^{3}$ and Diane L. Sturek ${ }^{3}$
}

\author{
* Correspondence: \\ mlowe@iupui.edu \\ ${ }^{1}$ IUPUI University Library, 755 W. \\ Michigan St, Indianapolis, IN 46202, \\ USA \\ Full list of author information is \\ available at the end of the article
}

\begin{abstract}
Introduction: This case study describes the process faculty at a large research university undertook to build a stand-alone online academic integrity course for first-year and transfer students. Because academic integrity is decentralized at the institution, building a more systematic program had to come from the bottom-up (faculty developed) rather than from the top down (institutionally mandated).

Case description: Using the learning management system, faculty and e-learning designers collaborated to build the course. Incorporating nuanced scenarios for six different types of misconduct (consistent with the University's Code of Student Rights, Responsibilities \& Conduct), a pre- and post-test, and assessments for each scenario, the course provides experience in recognizing and avoiding academic misconduct.

Discussion and evaluation: As a stand-alone course, the faculty who created it maintain control over content and are able to analyze student performance across the institution. In the ten months since its launch, the course has been eagerly adopted by faculty ( $n=$ 1853 students have completed the course) and post-test scores indicate students are learning from the course.
\end{abstract}

Conclusions: After the successful launch of the student course, the next step, already underway, is the launch of learning modules for faculty and teaching assistants.

Keywords: Academic integrity, Tutorial, Instructional technology

\section{$\triangle B M C$}

\section{Introduction}

Academic dishonesty is a recognized problem in higher education with a long history, dating back to Bowers' (1964) work in the 60s. Yardley et al. (2009) in a survey of college alumni found almost $82 \%$ reported cheating at some point in their undergraduate career. Martin, Rao, and Sloan (2009) in a sample of student work, rather than self-reported behavior, found $61 \%$ of students engaged in plagiarism. Ariely (2009) makes the case for vigilance against cheating with his "fudge factor theory." The cognitive flexibility, or rationalization to cheat a little bit, thereby benefiting from cheating, but still being able to view ourselves as honest human beings. Ariely (2012) also equates cheating to a virus, spreading person to person, and suggests that: "understanding how slippery slopes operate can direct us to pay more attention to early cases of transgression and help us apply the brakes before it is too late" (131).

(c) The Author(s). 2018 Open Access This article is distributed under the terms of the Creative Commons Attribution 4.0 International License (http://creativecommons.org/licenses/by/4.0/), which permits unrestricted use, distribution, and reproduction in any medium, provided you give appropriate credit to the original author(s) and the source, provide a link to the Creative Commons license, and indicate if changes were made. 
To address this seemingly ubiquitous problem, institutional responses, as well as who is responsible for the issue, vary. Responses range from relying on technology (institution) such as plagiarism-detection software (e.g., Heckler, Rice, and Bryan 2013; Youmans 2011) to policies (institution, students) such as honor codes (McCabe, Butterfield, and Trevino 2017; McCabe, Klebe, and Butterfield 2001) to pedagogy (faculty) in the form of stand-alone courses and modules embedded in other courses (e.g., Greer et al. 2012; Stephens and Wangaard 2016; Curtis et al. 2013). Lindsay (2018) asks faculty to consider to whom they have ethical responsibilities and makes the point: "it is awfully easy not to take formal action in cases of dishonesty. But then the question becomes: do you yourself - by your inaction - violate academia's code of ethics?" (7). It is in the faculty context that the current case description is grounded.

Academic integrity is decentralized at the authors' large, urban research institution. This decentralization creates a unique set of problems for faculty to educate students and fairly enforce key principles of academic integrity. As the individual institution is part of a multi-campus university, changing official university policies related to student conduct and students' rights would involve a difficult and protracted process. Additionally, at the campus level each academic unit uses a different process for handling cases of academic misconduct. Students taking classes across campus may receive conflicting information about the process for and consequence of similar offenses. Due to the varied procedures by unit, campus wide statistics on incidents of academic dishonesty are neither accurate nor complete. Information on the definitions, procedures, and sanctions for academic misconduct are not easy to find, and are written in legal terminology that is challenging for both students and faculty to access and understand. The uncertainty this decentralization causes is documented in a faculty survey the authors administered at their institution in 2017. While $48 \%$ of respondents $(n=51)$ think cheating is a serious problem at the university, $31 \%(n=33)$ are not sure if it is a serious problem. A majority of respondents $(55 \%, n=59)$ are not sure if the student judicial process is fair and impartial. When asked if they think faculty members are vigilant in discovering and reporting suspected cases of academic misconduct, 30\% $(n=32)$ disagree and 31\% $(n=33)$ are not sure. Most relevant to the intervention described in this paper, faculty rate student understanding of and support for university academic honesty policies as low.

Within this university context, how can concerned faculty approach the problem of educating, exemplifying, and enforcing academic integrity when going from the top-down (for example, changing institutional policies and procedures) is not feasible, especially in the short term? The literature provides options. At the institutional level, McCabe, Klebe, and Butterfield (2001), drawing on a decade of research on cheating in academic institutions, state the best way to impact student behavior is through institutional academic integrity programs and policies (for example, honor codes). East and Donnelly (2012) also approach the issue institutionally, by translating academic integrity issues into learning outcomes, which were then integrated into the university via a curriculum reform. This curricular approach led to a suite of resources to embed academic integrity into the curriculum, including modules for students and university staff, citation resources, and a website. Park (2004) details an institutional framework approach to plagiarism at Lancaster University, where the emphasis is on prevention and education, rather than punishment. Additionally, stakeholders throughout the institution (from students to faculty to administration) understand their roles and 
responsibilities. Importantly, McCabe, Klebe, and Butterfield (2001) state that individual classes can also influence behavior.

Online and in-person courses, as opposed to institutional interventions, are an alternative approach. Greer et al. (2012) report on the online academic integrity course at Oakland University. The scope of their online course is broad, going beyond university policies to discuss how and when to use sources, how to paraphrase and quote, and citation styles. Stephens and Wangaard (2016) describe their face-to-face academic integrity course, which is structured as a dialogue between teacher and students. From the teacher perspective, it includes professional development to help the teacher implement the seminar. Notably, both of these courses highlight the positive, academic integrity, rather than the negative, academic dishonesty.

Beyond stand-alone academic integrity courses, another alternative is course-embedded interventions. Curtis et al. (2013) describe the use of an academic integrity mastery test via a module embedded into a psychology course, which improved students' awareness of plagiarism. Lavine and Roussin (2012) link academic integrity issues to a real-world scenario related to students' majors through a semester-long academic integrity project in a management class. While intriguing, these course-specific solutions are not ideal in developing an intervention that could be deployed in a variety of classes and reach as many students as possible.

Drawing on the pros and cons of each type of intervention, for this project, the solution had to come from the ground-up. In other words, it had to be implemented in individual faculty classrooms but it also needed to be something that could reach as many students as possible. In this case, the authors' determined that the best way to educate students, especially incoming students unfamiliar with university policies and procedures on academic misconduct, was through a stand-alone online tutorial that any faculty member could assign to their class. This case study explains the process of creating and launching the tutorial as well as assessment and future directions.

\section{Case description}

Initially, this project started from a need for a group of faculty to form to discuss campus civility. These were Gateway faculty, faculty teaching large enrollment introductory courses. Interested faculty members met and discussed their concerns about campus civility. Members were interested either in how student's behavior affected the campus culture or academic misconduct procedures on campus. From this initial group, a faculty community of practice solely on academic integrity formed and originally conceived the intervention. The community of practice is composed of six faculty from a range of departments: science, business, liberal arts, engineering and technology, and the library. This is a good representation of the Gateway faculty on campus. The community of practice consulted with other campus bodies, including the office of student conduct and the faculty council to ensure this was an area of importance for the university. This group collaborated with e-learning design consultants in the university's information technology unit to develop and build the course. While the community of practice provided the subject content, e-learning consultants brought design services as well as structure to the project that kept the process on track and on time. See Table 1 for a timeline of events. 
The course, Learning with Integrity, was created in the learning management system (LMS), Canvas, which is an effective way to allow individuals within the university system to enroll in the course. (See Fig. 1 for a screenshot of the homepage.) The purpose of the course is to allow first-year or transfer students to self-enroll and complete the course. This is normally done when new students come to, or transfer into, the university and can be completed through an orientation or first-year seminar course. This stand-alone Canvas course is self-paced with a timed assessment at the conclusion and houses all the information to teach and assess undergraduate students on academic integrity. All students, undergraduate, graduate, and professional, as well as faculty and staff, including administrators, are able to join the Canvas course. The site is housed in the university's open access portal for online courses (named Expand) that consist of both non-credit and continuing education coursework. These courses are available to those within the university as well as the public. Therefore, individuals do not need to be associated with the university to enroll in the courses. There are a variety of courses available by topic, discipline, and delivery style. While some of the courses have a fee associated with enrollment, Learning with Integrity is free, available to university affiliated students, faculty, and staff, as well as the public.

The initial step in course creation was developing learning outcomes using the backward design method (Wiggins and McTighe 2006) on which to build assessments and learning materials. The identified learning goals are for the students to be able to recognize, explain, and avoid the various types of academic misconduct. The most common forms of academic misconduct are cheating and plagiarism (McCabe, Klebe

Table 1 Project timeline

\begin{tabular}{|c|c|}
\hline Date & Event/Project Milestone \\
\hline 2014 February & Community of Practice established \\
\hline $2014-2015$ & $\begin{array}{l}\text { - Research academic integrity policies at various universities nationwide } \\
\text { - Research procedures on various campuses within the university } \\
\text { - Research procedures within units on campus }\end{array}$ \\
\hline 2016 & $\begin{array}{l}\text { - Meet with the Office of Student Conduct and Faculty Council to report } \\
\text { findings } \\
\text { - Develop handouts for students and faculty about policy and procedures } \\
\text { on academic misconduct } \\
\text { - Survey faculty about the importance of academic integrity on campus } \\
\text { - Speak with various groups on campus to determine how to best reach } \\
\text { students }\end{array}$ \\
\hline 2017 July-August & $\begin{array}{l}\text { - Official collaboration between Community of Practice and e-learning } \\
\text { design consultants } \\
\text { - Outline of the course developed using backward design (e.g., learning } \\
\text { outcomes, presentation of materials such as videos, and assessments } \\
\text { such as quizzes) } \\
\text { - Discussion of course structure including scenarios for each type of } \\
\text { misconduct } \\
\text { - Start drafting scenarios }\end{array}$ \\
\hline 2017 September & $\begin{array}{l}\text { - Mock-up of site in LMS } \\
\text { - Scenarios writing for each type of misconduct completed }\end{array}$ \\
\hline 2017 November & Course ready to launch as pilot \\
\hline 2018 January-May & Course runs as pilot \\
\hline 2018 June-July & $\begin{array}{l}\text { Review of data, survey results, and faculty and student feedback to ensure } \\
\text { course is meeting learning outcomes }\end{array}$ \\
\hline 2018 August & $\begin{array}{l}\text { - Official course launch } \\
\text { - Open course for first-year seminar curriculum }\end{array}$ \\
\hline
\end{tabular}




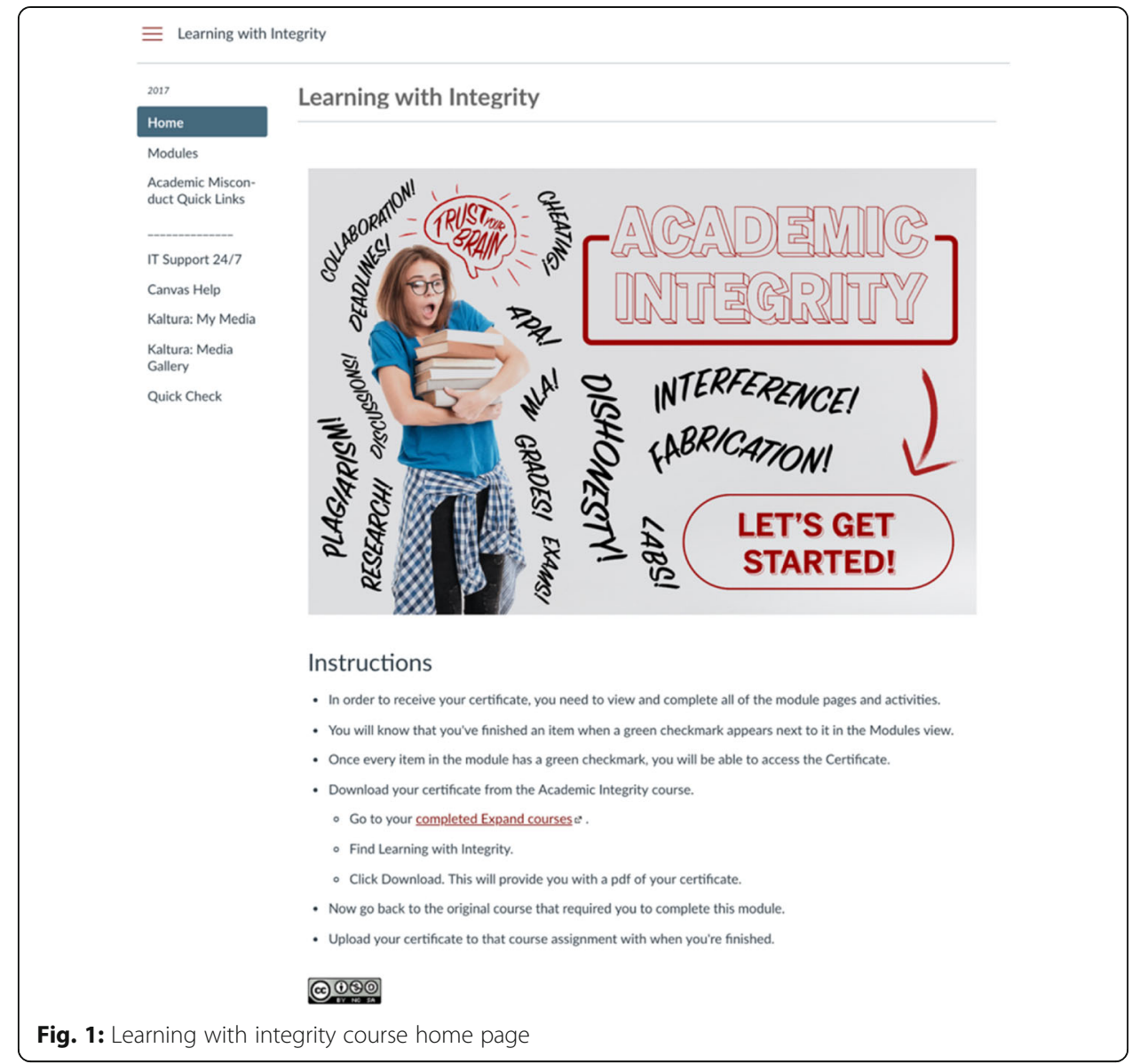

Trevino, and Butterfield 2001) which are also the easiest to recognize by the instructor. However, there are additional kinds of academic misconduct that are also unethical. The focus of the course is to teach the six different types of academic misconduct identified by the University's Code of Student Rights, Responsibilities \& Conduct: plagiarism, cheating, fabrication, interference, facilitating academic dishonesty, and violation of course rules.

The site's main focus is academic integrity and starts with defining the term as well as a video from the university's chief academic officer talking openly about the importance of academic integrity to the institution. This is meant to help students understand the importance of academic integrity to the reputation of the institution as well as to a student's academic career. (See Table 2 for an outline of the course.)

After the opening section, the course design includes a pre-test and then scenarios for each type of academic misconduct to help explain each act. Every scenario is presented as a video recording with student actors demonstrating each form of academic misconduct. After students complete the tutorial, optional follow-up in-class discussion led by the instructor allows for additional discussion about incidents of academic misconduct and the benefits of academic integrity. The overall purpose of each scenario is to use them as teachable moments for students and to have an informed, comfortable, and positive environment to discuss the topic. 
Table 2 Learning with integrity course outline

\begin{tabular}{ll}
\hline 1 & Page Titles \\
\hline 2 & Welcome to Academic Integrity \\
3 & What do you know about Academic Integrity? [pre-test] \\
4 & What are Academic Integrity and Misconduct? \\
5 & How do I keep my Academic Integrity? \\
6 & What happens if I commit Academic Misconduct? \\
& Where is Academic Misconduct likely to happen? \\
& Scenario 1 (Violation of Course Rules) [includes brief quiz] \\
& Scenario 2 (Cheating) [includes brief quiz] \\
& Scenario 3 (Fabrication) [includes brief quiz] \\
& Scenario 4 (Plagiarism) [includes brief quiz] \\
& Scenario 5 (Facilitation) [includes brief quiz] \\
& Scenario 6 (Interference) [includes brief quiz] \\
11 & What should I do if I witness Academic Misconduct? \\
\hline & My Key Takeaways \\
\hline & Post-Quiz [post-test] \\
& Satisfaction Survey \\
Certificate of Completion
\end{tabular}

There are multiple assessments built into the course. Participants are required to complete a seventeen-question pre-test to gauge their knowledge of the topic. This sets a baseline before students complete the course and allows comparison of their learning gains in understanding the topic after completion of the course. During the pre-test, students are assessed on their understanding of the six types of misconduct as well as how to find university information on the policies and procedures dealing with academic behavior. After watching videos for each scenario, three assessment questions follow, evaluating if the student can identify whether or not a situation is considered academic misconduct and why. These are delivered as short, multiple-choice questions. This is a good way to determine if the student understands the reason specific types of actions are considered academic misconduct. The team deliberately scripted each scenario to be complicated and nuanced in order to ensure students would be required to use resources to determine the answer.

At the end of the course, students complete a seventeen-question post-test (identical to the pre-test), which assesses their knowledge on the types of academic misconduct, what happens if they are involved with academic misconduct, and how to avoid academic misconduct in the future. This is a timed, multiple choice quiz, where various scenarios are given and must be identified (see Additional file 1: Appendix). Pre and post-test questions were developed to specifically address the nuances of the six different types of misconduct identified by the university. They are worded so students need to think not only if a question scenario is misconduct (yes or no) but also the reason why. For example, Yes, it is misconduct because, or no, it is not misconduct because. The rationale for including the "why" was to prompt students to think about the consequences or implications and to lessen the chance of guessing the correct answer.

At the completion of the course, a student must receive $75 \%$ or higher on the post-test after two attempts at which point a "certificate of completion" is produced. 
The certificate is an electronic file that can be shared with faculty requiring the course for credit and displays the student's name and course completion date, which cannot be altered. Finally, to determine students' perceptions of the course as well as its usability, a seven-question satisfaction survey is included in the course after the post-test. Consisting of a mix of Likert scale and open-ended questions, it attempts to gauge student perceptions of the course as well as its usability (see Table 3).

After the initial pilot launch of the course (see Table 1), the course developers examined student quiz scores to determine if specific questions were commonly missed, indicating poor question wording. Student answers to the usability questions were also examined to ensure there were no issues raised related to course design. There were no glaring issues in either area (see Discussion and Evaluation section, below, for more detailed information about the usability survey data). Additionally, faculty early adopters who deployed the course in their classes were encouraged to send their feedback to the developers. Feedback indicated some confusion on how students successfully completed the course and obtained the certificate of completion. To address this confusion, an introductory page was added to the module including instructions on how students know they are finished with the site and can print their certificate of completion (see Fig. 2). Anecdotally, student and faculty feedback was overwhelmingly positive regarding course content.

\section{Discussion and evaluation}

There were many advantages to developing a stand-alone academic integrity course in the learning management system (LMS). First, the LMS format is familiar to everyone at the institution, not only the students but also the e-learning designers and faculty, so there is not a learning curve as their might be if a separate tutorial tool (e.g., Adobe Captivate) was used. Second, because it was built as a separate course, and is not able to be integrated into another Canvas course, the faculty who developed the course can monitor student academic integrity performance across the university. If the content of the course was integrated into another site, that compilation of data would be lost. Third, as all students at the university enroll in the same Canvas course, looking at the current knowledge of students can help determine with what concepts students are more or less familiar. Poor scores on topics might mean these areas need better description or explanation. Fourth, having one site allows the instructional team to change and develop content relevant to the data collected. This information can also be shared with other groups about the importance of teaching students about academic

Table 3 Student course satisfaction survey questions

\begin{tabular}{ll}
\hline Question & Type \\
\hline wow much do you agree with the following statement: I am satisfied & Likert (4-point scale) \\
Please rate the following statement: The course was easy to navigate. & Likert (5-point scale) \\
What did you find to be the most helpful parts of this module? & Open-ended \\
What two things would you like to see improved? & Open-ended \\
Were there any unclear points in the module? If so, what are they? & Open-ended \\
Which topic would you like to know more about? & List of the six types of misconduct \\
Other comments? & (choose multiple) \\
\hline
\end{tabular}




\section{Instructions}

- In order to receive your certificate, you need to view and complete all of the module pages and activities.

- You will know that you've finished an item when a green checkmark appears next to it in the Modules view.

- Once every item in the module has a green checkmark, you will be able to access the Certificate.

- Download your certificate from the Academic Integrity course.

- Go to your completed Expand courses $\mathrm{L}^{2}$.

○ Find Learning with Integrity.

- Click Download. This will provide you with a pdf of your certificate.

- Now go back to the original course that required you to complete this module.

- Upload your certificate to that course assignment with when you're finished.

Fig. 2: Instructions on site homepage

integrity. Fifth, the certificate of completion means a student does not have to take the course multiple times in multiple classes but can demonstrate knowledge to their professor through the certificate.

There were also, of course, disadvantages to the course format. First, the inability of a faculty member to port parts of the course directly into their LMS course means faculty must rely on the certificate of completion to determine student competency. Second, stand-alone also means a faculty member does not have the ability to modify the course to meet their specific needs. Third, producing the course took time and required collaboration across campus units. Although the faculty community of practice could have built the course, the e-learning design collaboration allowed for a more visually appealing and robust course, especially in the areas of video production and graphic design. This level of support may not be available to faculty at other institutions seeking to develop their own academic integrity course.

The effectiveness of the course varies based on assessment data but indicates students are learning from the course and enjoy the format. From the pilot (see Table 1), students correctly answered $76 \%$ of pre-test, $85-94 \%$ of individual scenario, and $90 \%$ of post-test questions. The average percentage on the pre-test, each of the six scenarios, and post-test are in Table 4. The three question quizzes after each video are scenario

Table 4 Pre-, post-test and scenario quiz scores

\begin{tabular}{|c|c|c|c|c|c|c|c|}
\hline$\overline{\text { Quiz }}$ & Module & $n$ & $\begin{array}{l}\text { Number of } \\
\text { Questions }\end{array}$ & $\begin{array}{l}\text { Percentage } \\
\text { Correct Responses }\end{array}$ & Mean & Range & $\begin{array}{l}\text { Standard } \\
\text { Deviation }\end{array}$ \\
\hline Pre-Test & & 2278 & 17 & $76 \%$ & 12.94 & 15 & 2.79 \\
\hline $\begin{array}{l}\text { Post-Test (identical } \\
\text { to pre-test) }\end{array}$ & & $2691^{a}$ & 17 & $90 \%$ & 15.36 & 16 & 1.98 \\
\hline \multirow[t]{6}{*}{$\begin{array}{l}\text { Scenarios (unique } \\
\text { to each scenario) }\end{array}$} & $\begin{array}{l}1 \text { (Violation of } \\
\text { Course Rules) }\end{array}$ & 1391 & 3 & $85 \%$ & 2.54 & 3 & 0.66 \\
\hline & 2 (Cheating) & 1176 & 3 & $93 \%$ & 2.80 & 3 & 0.48 \\
\hline & 3 (Fabrication) & 1213 & 3 & $89 \%$ & 2.66 & 3 & 0.56 \\
\hline & 4 (Plagiarism) & 1145 & 3 & $93 \%$ & 2.78 & 2 & 0.45 \\
\hline & 5 (Facilitation) & 1157 & 3 & $91 \%$ & 2.73 & 3 & 0.48 \\
\hline & 6 (Interference) & 1108 & 3 & $94 \%$ & 2.82 & 3 & 0.41 \\
\hline
\end{tabular}

aincludes multiple attempts 
specific, intended as formative assessments, and are not related to the identical pre and post-tests. From the pre-test to the post-test, a repeated measures one-way analysis of variance (ANOVA) showed a significant effect, $F(1,4967)=1272.25, p<.001$. Cohen's $d=-1.00035450$ indicating a large effect size. The pre-test scores would indicate that the course is necessary, as a quarter of students taking the course are not familiar with all the types of academic misconduct or if something qualifies as academic misconduct. After taking the course, $90 \%$ of students score well on the post-test, demonstrating they have learned the nuances of the types of academic misconduct. Since the course launched in November 2017 through August 2018, a total of $n=2411$ students have registered for the course with $n=1853$ having completed the course, a 77\% completion rate. As mentioned above, students must score $75 \%$ or higher on the post-test to complete the course and have two chances to take the test. Of the $n=1853$ who have completed the course, $45 \%(n=842)$ had to take the post-test both times. The developers are reviewing this data to determine if that is an acceptable rate or if the quiz is too hard.

Results from the satisfaction survey indicate students are satisfied with the course and its design. On a 4-point Likert scale (1-Strongly Disagree to 4-Strongly Agree) student responses $(n=1716)$ average 3.04 (Agree) for the question: "How much do you agree with the following statement: I am satisfied with my experience with this module." For the usability question "Please rate the following statement: The course was easy to navigate" on a 5-point Likert scale (1-Strongly Disagree to 5-Strongly Agree with 3-Neutral) student responses $(n=1717)$ average 4.01 (Agree). The addition of neutral for the usability question, which is missing from the satisfaction question, was done deliberately. Developers wanted to know if students were satisfied with the course without an option to "opt-out" by choosing neutral. However, with the usability question, navigation could be a neutral response, in that it was neither hard nor easy to navigate.

In open-ended responses to the question "What did you find to be the most helpful parts of this module" $(n=1622)$ almost half of students note the video scenarios as the most helpful $(n=753,46 \%)$. Students also stated knowing university policy on academic misconduct was helpful. For the question, "What two things would you like to see improved?" ( $n=1579)$ almost a fifth $(n=268,17 \%)$ indicated the length of the course. However, as it is important to cover each type of misconduct and the course only takes approximately an hour for students to complete, this suggestion is challenging to remedy. Answers to the question "Which topic would you like to know more about" $(n=1635)$ support the idea that cheating, violation of course rules, and

Table 5 Satisfaction survey - types of misconduct students would like to know more about

\begin{tabular}{ll}
\hline Type of Misconduct & Number of Students $\left(n=1635^{\mathrm{a}}\right)$ \\
\hline Facilitation & $795(49 \%)$ \\
Interference & $642(39 \%)$ \\
Fabrication & $589(36 \%)$ \\
Plagiarism & $349(21 \%)$ \\
Violation of course rules & $299(18 \%)$ \\
Cheating & $101(6 \%)$ \\
\hline
\end{tabular}

The overall total exceeds $n=1635$ as respondents can choose more than one answer 
plagiarism are fairly well understood by students, but other types of misconduct are not. (See Table 5.)

\section{Conclusions}

The faculty have learned a great deal through the nearly yearlong process to develop, build, and launch the Learning with Integrity course and in the ten months since the launch. Due to the previously mentioned campus decentralization, aggressive marketing and promotion has been required to raise awareness about, and get buy-in for, the course. In almost all cases, faculty enthusiastically receive the course. However, it takes time to do this promotion and the faculty who developed the course have heavy teaching responsibilities. Another issue with any digital learning object is upkeep, ensuring the course is accurate, current, and relevant to students. Regular maintenance is necessary and is something for which the group is still working on developing a long-term sustainability plan.

The logical next step from a student-centered course is a faculty and teaching assistant (TA) focused course. Work on the faculty/TA course has already begun due to interest from the campus teaching and learning center who coordinate the TA orientation. Building on the scenarios from the student modules, the faculty/TA course will contain scenarios and information for what instructors should do when academic dishonesty happens in a course they are teaching. An unexpected next step is that, because the course is licensed under a Creative Commons Attribution-NonCommerical-ShareAlike License, other campuses have begun adapting the material for their own unique situations. Faculty and e-learning designers have been collaborating as necessary on these adaptations.

Learning with Integrity, a stand-alone course in the LMS, has allowed a large, decentralized university to programmatically and systematically teach first-year and transfer students about the types of academic misconduct and the university policies surrounding them. This has resulted in greater faculty and student awareness of the issues and has the potential to provide a platform on which to build a more holistic university-wide academic integrity program.

\section{Additional file}

Additional file 1: Appendix. Pre and post-test questions. (DOCX 29 kb)

Abbreviations

ANOVA: Analysis of Variance; LMS: Learning Management System; TA: Teaching Assistant

Acknowledgements

not applicable.

Funding

not applicable.

Availability of data and materials

not applicable.

Authors' contributions

MSL drafted the majority of the article as well as formatting, submission, and the bulk of data analysis. GLS drafted the remainder of the article and data analysis. KW edited the manuscript and added content to the introduction. DS edited the article. All authors read and approved the final manuscript. 


\section{Publisher's Note}

Springer Nature remains neutral with regard to jurisdictional claims in published maps and institutional affiliations.

\section{Author details}

${ }^{1}$ IUPUI University Library, 755 W. Michigan St, Indianapolis, IN 46202, USA. ${ }^{2}$ IUPUI School of Science, 402 N. Blackford St, Indianapolis, IN 46202, USA. ${ }^{3}$ IUPUI, Kelley School of Business, 801 W. Michigan St, Indianapolis, IN 46202, USA.

Received: 5 September 2018 Accepted: 14 November 2018

Published online: 27 December 2018

\section{References}

Ariely D (2009) Our buggy moral code. TED Talk. www.ted.com/talks/dan_ariely_on_our_buggy_moral_code. Accessed 31 Aug 2018

Ariely D (2012) The honest truth about dishonesty. Harper Collins, New York

Bowers WJ (1964) Student dishonesty and its control in college. Columbia University, New York

Curtis GJ, Gouldthorp B, Thomas EF, O'Brien GM, Correla HM (2013) Online academic-integrity mastery training may improve students' awareness of, and attitudes toward, plagiarism. PLAT 12(3):282-289. https://doi.org/10.2304/plat.2013.12.3.282

East J, Donnelly L (2012) Taking responsibility for academic integrity: a collaborative teaching and learning design. JULTP 9(3):1-11

Greer K, Swanberg S, Hristova M, Switzer AT, Daniel D, Perdue SW (2012) Beyond the web tutorial: development and implementation of an online, self-directed academic integrity course at Oakland University. J Acad Lib 38(5):251-258. https://doi.org/10.1016/.acalib.2012.06.010

Heckler NC, Rice M, Bryan CH (2013) Turnitin systems: a deterrent to plagiarism in college classrooms. J Res Tech Ed 45(3): 229-248. https://doi.org/10.1080/15391523.2013.10782604

Lavine MH, Roussin CJ (2012) From idea to action: promoting responsible management education through a semester-long academic integrity learning project. J Mgmt Ed 36(3):428-455

Lindsay P (2018) The craft of university teaching. University of Toronto Press, Toronto

Martin DE, Rao A, Sloan LR (2009) Plagiarism, integrity, and work-place deviance: a criterion study. Ethics Behav 19(1):36-50. https://doi.org/10.1080/10508420802623666

McCabe DL, Klebe Trevino L, Butterfield KD (2001) Cheating in academic institutions: a decade of research. Ethics Behav 11(3): 219-232. https://doi.org/10.1207/S15327019EB1103_2

McCabe DL, Butterfield KD, Trevino LK (2017) Cheating in college: why students do it and what educators can do about it. Johns Hopkins University Press, Baltimore

Park C (2004) Rebels without a clause: towards an institutional framework for dealing with plagiarism by students. J Furth High Ed 28(3):291-306. https://doi.org/10.1080/0309877042000241760

Stephens JM, Wangaard DB (2016) The achieving with integrity seminar: an integrative approach to promoting moral development in secondary school classrooms. Intl J Ed Int 12(3):1-16. https://doi.org/10.1007/s40979-016-0010-1

Wiggins G, McTighe J (2006) Understanding by design. Pearson, Upper Saddle River

Yardley J, Rodriguez MD, Bates SC, Nelson J (2009) True confessions? Alumni's retrospective reports on undergraduate cheating behaviors. Ethics Behav 19(1):1-14. https://doi.org/10.1080/10508420802487096

Youmans RJ (2011) Does the adoption of plagiarism-detection software in higher education reduce plagiarism? St High Ed 36(7):749-761. doi: https://doi.org/10.1080/03075079.2010.523457

Ready to submit your research? Choose BMC and benefit from:
- fast, convenient online submission
- thorough peer review by experienced researchers in your field
- rapid publication on acceptance
- support for research data, including large and complex data types
- gold Open Access which fosters wider collaboration and increased citations
- maximum visibility for your research: over 100M website views per year
At BMC, research is always in progress.
Learn more biomedcentral.com/submissions

